\title{
OPTIMALISASI MEDIA SOSIAL SEBAGAI ALAT PROMOSI UNTUK DESA WISATA LEBAKMUNCANG
}

\author{
Hapsari Setyowardhani*1, Hera Susanti ${ }^{2}$, Riyanto ${ }^{3}$ \\ ${ }^{1}$ Departemen Manajemen, ${ }^{2,3}$ Departemen Ilmu Ekonomi \\ 1,2,3 Fakultas Ekonomi dan Bisnis Universitas Indonesia, Kampus Widjojo Nitisastro \\ Jl. Prof. Dr. Sumitro Djojohadikusumo Kampus UI Depok, Jawa Barat, Indonesia, 16424 \\ $\mathrm{T}:+62217272425,+62217272646$ \\ F : +62 217272649 \\ *E-mail: hapsari.setyowardhani@gmail.com,
}

\begin{abstract}
Community-based Tourism has now developed into an alternative form of tourist destination that is in great demand. One special form of Community-based Tourism is Tourism Village. The Tourism Village in the last five years has been growing along with the number of Field Study Programs or Live in the Villages Programs required by Senior High Schools (SMA) and Real Work Lecture Programs in Universities. Based on the results of interviews and observations from the Community Service Team, Faculty of Economics and Business, Universitas Indonesia, we found that Tourism Village was visited by tourists, especially from Millennials because it was supported by promotions through social media, namely Youtube, Website, Instagram, and Facebook. So that the Lebakmuncang as the Tourism Village should manage its social media more seriously, as the spearhead of promotional activities.
\end{abstract}

Keywords-Community-based Tourism, Tourism Village, Promotion, Social Media

\begin{abstract}
Abstrak
Pariwisata Berbasis Komunitas (Community-based Tourism) saat ini telah berkembang menjadi salah satu bentuk alternatif destinasi wisata yang banyak diminati. Salah satu bentuk khusus dari Pariwisata Berbasis Komunitas adalah Desa Wisata. Desa Wisata dalam lima tahun terakhir ini makin berkembang seiring dengan banyaknya Program Studi Lapangan atau Program Turun ke Desa yang diwajibkan oleh Sekolah-sekolah Menengah Atas (SMA) dan Program Kuliah Kerja Nyata yang diwajibkan oleh Perguruan Tinggi/Universitas. Berdasarkan hasil wawancara dan observasi dari Tim Pengabdian Masyarakat, Fakultas Ekonomi dan Bisnis, Universitas Indonesia, maka kami menemukan bahwa Desa Wisata banyak dikunjungi oleh wisatawan terutama oleh Generasi Millenial karena didukung oleh promosi lewat media sosial, yaitu Youtube, Website, Instagram, dan Facebook. Sehingga Desa Wisata Lebakmuncang sebagai salah satu Desa Wisata sebaiknya mengelola media sosial yang dimilikinya dengan lebih serius, sebagai ujung tombak dari kegiatan promosi
\end{abstract}

Keywords-Pariwisata Berbasis Komunitas, Community-based Tourism, Desa Wisata, Promosi, Media Sosial

\section{PENDAHULUAN}

Pariwisata Berbasis Masyarakat atau Community-based Tourism (CBT) adalah bentuk pariwisata di mana masyarakat lokal memiliki kendali yang dominan, dan terlibat dalam pengembangan dan pengelolaannya, dan sebagian besar manfaatnya dapat dirasakan oleh masyarakat lokal itu sendiri. Gagasan CBT menekankan pada partisipasi aktif dan pemberdayaan masyarakat lokal dalam pengelolaan kegiatan pariwisata [1]. CBT melibatkan masyarakat setempat dalam perencanaan, pemeliharaan, pengembangan pariwisata yang berkelanjutan/suistanable [2]. CBT merupakan hubungan yang lebih saling menguntungkan antara masyarakat dan wisatawan, dengan keterlibatan wisatawan di dalam sistem [3]. 
Sebagian besar literatur kontemporer dan dokumen kebijakan tentang CBT telah mengidentifikasi tiga kriteria utama dari CBT [4], yaitu CBT berada di dalam sebuah komunitas masyarakat, dimiliki oleh satu atau lebih anggota masyarakat, dan dikelola oleh anggota masyarakat (termasuk terlibat dalam proses pengambilan keputusan). Ketiga kriteria ini memungkinkan berbagai bentuk pengorganisasian CBT, seperti penyediaan layanan pariwisata oleh keluarga atau masyarakat secara bergantian dan dalam jangka waktu tertentu; outsourcing layanan pariwisata kepada beberapa anggota masyarakat; dan program pendampingan masyarakat oleh Dinas Pawisata setempat dalam pengambilan keputusan dan pengelolaan CBT [4].

Pariwisata berbasis masyarakat dapat meningkatkan kehidupan ekonomi rumah tangga lokal, dan meningkatkan kesadaran masyarakat lokal tentang pelestarian alam. Pariwisata berbasis masyarakat dengan tata kelola yang baik dapat menghasilkan manfaat ekonomi, ekologi, dan sosial [5], berkontribusi secara substansial untuk meningkatkan pendapatan di daerah pedesaan. Oleh karena itu, pengembangan pariwisata berbasis masyarakat adalah solusi bagi pengentasan kemiskinan di daerah pedesaan [5], Pariwisata berbasis pedesaan perlu dikembangkan karena akan mendorong pertumbuhan ekonomi pedesaan, memperluas lapangan kerja pedesaan yang pada akhirnya akan meningkatkan kesejahteraan rakyatnya. Masalah demografis yang sering muncul di daerah pedesaan akan dapat diatasi melalui pengembangan pariwisata, seperti migrasi orang muda ke kota, pengangguran, penurunan populasi, dll [5].

Di Indonesia, pariwisata berbasis pedesaan dikenal sebagai desa wisata. Pariwisata berbasis desa atau desa pariwisata adalah salah satu cara untuk menerapkan pengembangan pariwisata berbasis masyarakat yang berkelanjutan [6].

Salah satu desa wisata di Indonesia adalah Desa Wisata Lebakmuncang. Desa Lebakmuncang berlokasi di Jl. Lebakmuncang No. 17 Kecamatan Ciwidey Kabupaten Bandung, Jawa Barat. Desa yang terletak di dataran tinggi dengan ketinggian 1200 meter di atas permukaan laut ini berhawa sejuk dengan suhu rata-rata $18^{\circ}-20^{\circ} \mathrm{C}$. Desa yang ditetapkan menjadi Desa Wisata berdasarkan SK dari Bupati ini mengangkat tema Agroedukasi dan Orientasi Budaya [7].

Produk atau Program wisata yang ditawarkan adalah :

1. Edukasi Pertanian (Agricultural Education)

Program Edukasi pertanian di Lebakmuncang, wisatawan dapat belajar cara menanam, memelihara, memanen dan memasarkan hasil-hasil pertanian di Lebakmuncang. Hasil pertanian terbanyak di Lebakmuncang adalah Seledri, Bawang, Tomat, Strawberry, dan Jamur. Wisatawan juga dapat melakukan praktek langsung dengan mengikuti Program Sehari Menjadi Petani atau Leledokan.

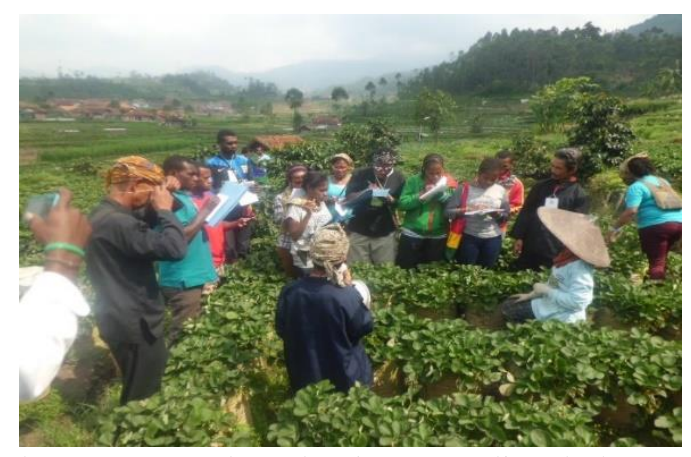

Gambar 1. Agricultural Education di Lebakmuncang

2. Kegiatan di Alam Terbuka (Outdoor Activity Program)

Kegiatan alam terbuka yang dapat dinikmati di Lebakmuncang adalah Jungle Tracking, yaitu mengenal alam sekitar, menikmati pemandangan dari puncak bukit, sambal menikmati makanan khas desa wisata seperti liwet di puncak bukit (Sapoe di Gunung/Ngaliwet). 


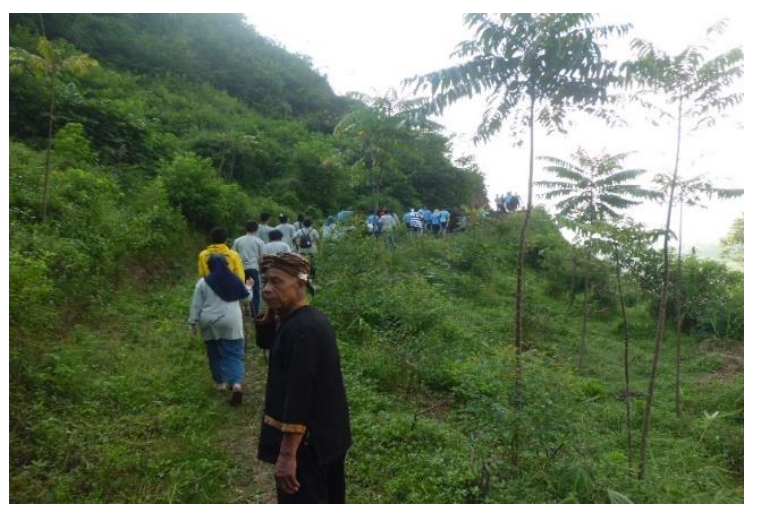

Gambar 2. Outdoor Activity Program di Lebakmuncang

\section{Edukasi Budaya (Cultural Education)}

Lebakmuncang juga menawarkan program pengenalan terhadap budaya dan adat istiadat setempat, yang berupa pertunjukan kesenian seperti Degung, Bangkong Reang, dan Jaipong. Wisatawan juga dapat mempelajari dan memainkan alat musik tradisional tersebut.

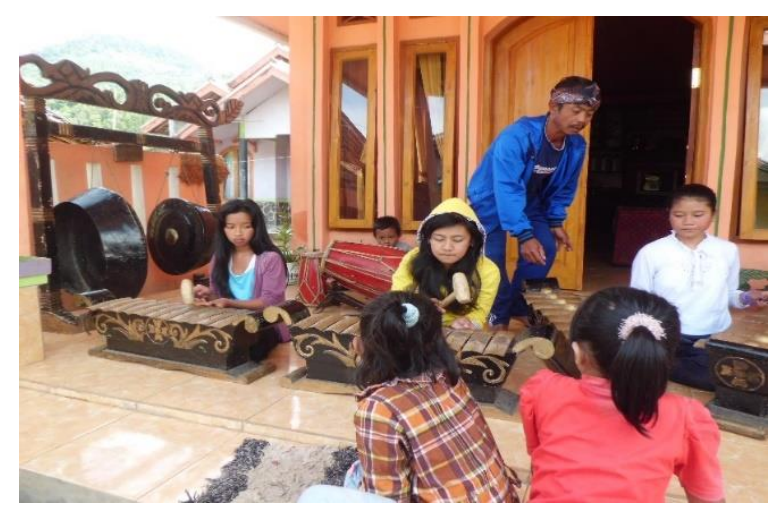

Gambar 3. Cultural Education di Lembakmuncang

4. Edukasi Khusus (Specialties Education)

Dalam edukasi khusus ini, para pengunjung dapat juga mempelajari cara membuat makanan khas tradisional Lebakmuncang, seperti Rangginang, Rangening, Saroja, Dodol Stawberry dan makanan khas lainnya.

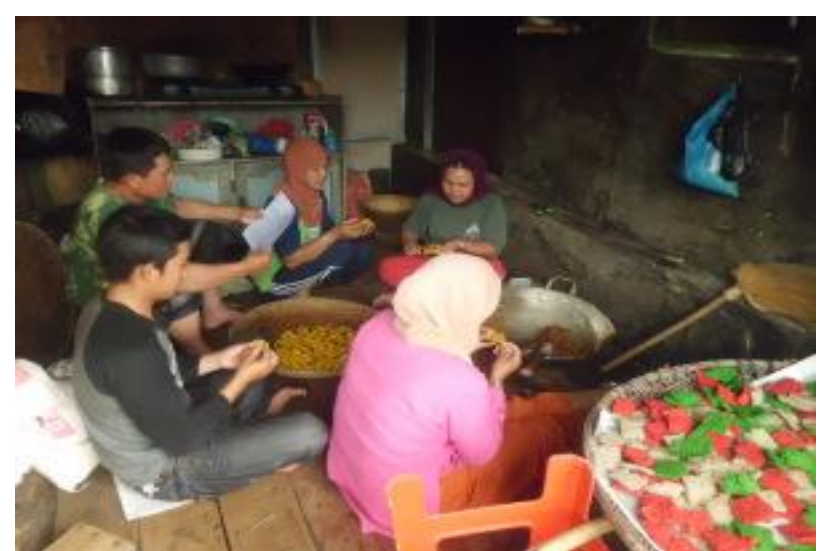

Gambar 4. Specialties Education di Lebakmuncang

\section{Homestay}

Desa Wisata Lebakmuncang juga menyediakan akomodasi berupa Homestay dengan suasana khas dan asli rumah pedesaan dengan konsep live in atau tinggal di rumah warga desa. Homestay juga termasuk menyediakan makanan tiga kali sehari dengan menu khas pedesaan. 


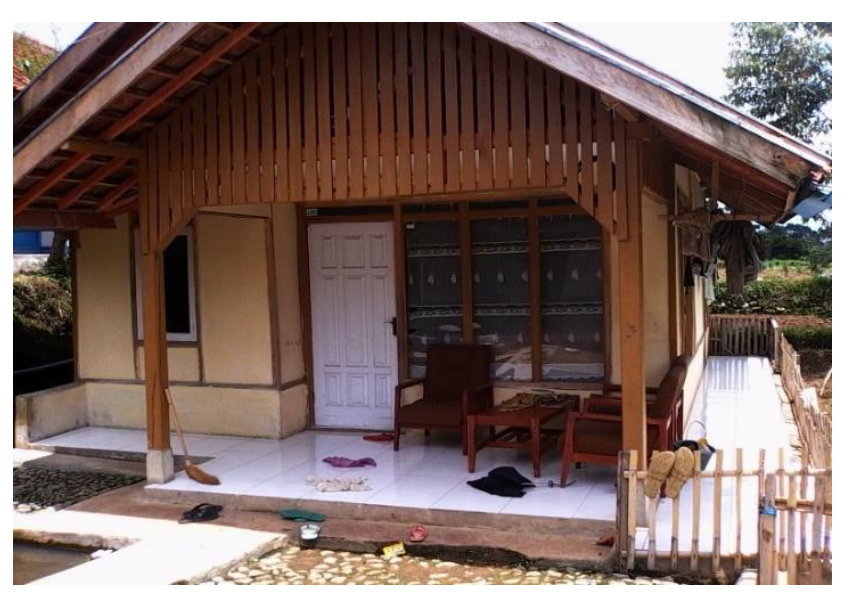

Gambar 5. Homestay in Lebakmuncang

Tim Dosen Universitas Indonesia melakukan kegiatan Penelitian sekaligus Pengabdian Masyarakat dengan mengadakan program pendampingan terhadap para Pengurus dan Anggota Kelompok Pemerhati Pariwisata (Kompepar) Kabupaten Cianjur. Salah satu kegiatan yang dilakukan adalah melakukan kunjungan ke Desa Wisata Lebakmuncang. Kegiatan ini dilakukan sebagai bentuk studi banding bagi para Pengurus Kompepar, tentang bagaimana pengelolaan tempat wisata berbasis komunitas/masyarakat (Community-based Tourism). Kami tertarik untuk mendatangi desa wisata ini karena melihat video-video yang diunggah ke Youtube. Video-video ini menjadi salah satu daya tarik dari wisatawan untuk berkunjung ke Lebakmuncang. Dalam artikel ini, penulis mendiskusikan tentang bagaimana media sosial dapat menjadi alat promosi yang efektif untuk meningkatkan daya tarik wisata, termasuk strategi promosi lewat media sosial yang dilaksanakan oleh Pokja Desa Wisata Lebakmuncang.

\section{METODE}

Kunjungan Tim UI dengan membawa rombongan para anggota Kompepar Cianjur pada Oktober 2018, adalah bagian dari rangkaian kegiatan pelaksanaan Penelitian dan Pengabdian Masyarakat dengan Skema Pendaanaan Penelitian Terapan Unggulan Perguruan Tinggi (PTUPT) 2018. Sebelum melaksanakan kegiatan kunjungan ke Desa Wisata Lebakmuncang, Tim UI melaksanakan pertemuan dan koordinasi terlebih dahulu dengan Dinas Pariwisata, Kepemudaan, dan Olah Raga (Dispapora) Cianjur, untuk mendiskusikan kegiatan kerja sama apa saja yang dapat dilakukan antara Tim UI dan Dispapora Cianjur dalam meningkatkan peran Kompepar sebagai ujung tombak dari pengembangan pariwisata di wilayah Cianjur (Metode wawancara dengan Kepala Bidang beserta jajaran Dispapora Cianjur).

Setelah mengadakan pertemuan dan koordinasi, maka disepakati bahwa salah satu program yang dilaksanakan adalah melaksanakan Studi Banding ke Desa Wisata Lebakmuncang, Bandung. Adapun tujuan dari kegiatan ini adalah untuk memberikan wawasan tentang pengelolaan sebuah Desa Wisata kepada para Pengurus dan Anggota Kompepar Cianjur.tentang pengelolaan Desa Wisata. Sehingga Kompepar dapat belajar dari pengelolaan wisata yang dilakukan di Lebakmuncang.

Sebelum memilih Desa Wisata Lebakmuncang, Tim UI melakukan pencarian informasi di berbagai media sosial tentang desa wisata (Metode pengumpulan data sekunder digital). Setelah mengumpulkan berbagai informasi, dan kemudian mempertimbangkan lokasi, jarak, dan aksesibilitas, maka akhirnya kami memilih Desa Lebakmuncang sebagai tempat dari kegiatan studi banding kami.

Selama Tim UI melaksnakan kunjungan di Desa Lebakmuncang, kami mengikuti rangkaian kegiatan yang dipandu oleh Ketua Kelompok Kerja (Pokja) setempat, sekaligus pada saat kami mengikuti kegiatan, kami juga melakukan observasi terhadap lingkungan di sekitar Lebakmuncang. Misalnya pada saat kami melakukan tracking, jalan-jalan ke sawah dan bukit, kami sekaligus mengamati kondisi lahan pertanian di Lebakmuncang dan juga masyarakatnya (Metode Observasi). 
Selain itu kami juga sempatkan untuk berdiskusi dengan Ketua Pokja dan juga masyarakat setempat (Metode Wawancara).

Seluruh informasi tersebut kemudian kami analisis dengan metode analisis konten sederhana, yaitu dengan merangkum dan merangkai seluruh sumber informasi yang kami dapatkan, baik rekaman dan catatan hasil wawancara dan diskusi, catatan hasil observasi, serta foto dan video yang kami dokumentasikan. Pembahasan pada artikel ini lebih ditekankan kepada pemaparan hasil observasi dan wawancara selama berada di Lebakmuncang. Selain itu artikel ini juga membahas tentang efektivitas media sosial yang digunakan oleh Desa Wisata Lebakmuncang dalam mempromosikan daerah wisata nya. Strategi ini yang kemudian nantinya dapat dijadikan benchmark oleh para Pengurus dan Anggota Kompepar Cianjur dalam dalam menyusun strategi promosi daerah wisata masing-masing.

\section{HASIL DAN PEMBAHASAN}

Berdasarkan hasil wawancara dengan Ketua Pokja Desa Wisata Lebakmuncang, yaitu Kang Asep Ahmad Sopian, pengelolaan Desa Wisata Lebakmuncang ditangani oleh Ketua Pokja, Anggota Pokja, Sesepuh Desa, Perangkat Desa, dan didukung oleh para Warga Desa Lebakmuncang. Ketika ada tamu atau wisatawan yang akan datang berkunjung ke Desa Lebakmuncang, maka Ketua Pokja lah yang mengkoordinasikan atraksi apa saja yang akan ditampilkan oleh warga dan kegiatan apa saja yang dilakukan selama wisatawan datang berkunjung beserta siapa yang kan bertanggung jawab menananganinya. Selain itu, Ketua Pokja juga mengatur rumah siapa saja yang ditempati sebagai Homestay untuk wisatawan, termasuk kesepakatan menu yang diberikan oleh pemilik Homestay selama mereka menginap di Lebakmuncang.

Berdasarkan sistem pengelolaan Desa Wisata Lebakmuncang tersebut, maka dapat dikatakan bahwa pengelolaan Desa Wisata Lebakmuncang sesuai dengan karakteristik dari Pariwisata berbasis Komunitas (Community-based Tourism). Desa Wisata melibatkan masyarakat dalam pengelolaannya [1], serta merupakan kegiatan pariwisata yang menguntungkan masyarakat, karena memberikan sumber pendapatan bagi para warga desa, dengan melibatkan para pengunjung atau wisatawan di dalam kegiatannya [2]. Pembagian jadwal penggunaan rumah untuk Homestay, siapa saja yang bertanggung jawab dalam pelaksanaan kegiatan selama wisatawan berkunjung, merupakan bentuk pengaturan pengelolaan sebuah Community-based Tourism [4]. Dukungan dari Dinas Pariwisata setempat juga didapatkan dengan adanya pengesahan sebagai desa wisata berdasarkan Surat Keputusan dari Kepala Pemerintahan setempat, yaitu Bupati Bandung [7].

Berdasarkan hasil observasi salama kunjungan ke Lebakmuncang, pada saat Tim UI beserta Kompepar berkunjung ke Desa Lebakmuncang, kami disambut oleh alunan musik dan lagu khas dari Tanah Parahyangan, yang kemudian sekaligus dilanjutkan oleh acara penyambutan oleh Ketua Pokja dan Sesepuh Desa. Setelah itu kami dipandu oleh beberapa tour-guide yang membawa kami melihat area persawahan di Lebakmuncang. Malamnya kami berdiskusi dengan Ketua Pokja, Sesepuh Desa, dan Perangkat Desa tentang sistem pengelolaan wisata di Lebakmuncang. Pagi harinya, dengan dipandu oleh tour-guide, kami mendaki bukit dan sarapan (Ngaliwet) di puncak bukit. Selama kami menginap di Homestay, kami juga merasakan hidup bersama (live-in) bersama pemilik Homestay.

Kami pun banyak berbincang dengan pemilik Homestay pada saat makan bersama mereka. Kegiatan yang kami rasakan memang seperti yang dipromosikan di media sosial Desa Wisata Lebakmuncang, baik di Website, Facebook, dan Youtube. Keunikan dan keunggulan yang ditawarkan oleh Desa Lebakmuncang memang terletak pada keaslian suasana pedesaan yang ditawarkan, termasuk kondisi rumah yang dijadikan Homestay oleh penduduk desa, yang apa adanya sesuai kemampuan ekonomi pemilik rumah. Namun untuk sebagian besar wisatawan yang berkunjung ke Lebakmuncang, keaslian suasana pedesaan inilah yang dicari, apalagi mereka yang biasa tinggal di perkotaan dan tidak pernah melihat suasana seperti ini di tempat tinggalnya.

Dari hasil wawancara dan diskusi dengan Pokja dan para warga setempat, sebagian besar tamu yang datang ke Lebakmuncang adalah anak-anak muda, yaitu anak-anak SMA yang mengikuti kegiatan Hidup di Desa (Live-in) yang diwajibkan oleh pihak sekolah. Selain itu banyak juga mahasiswa yang mengikuti program Kuliah Kerja Nyata (KKN) selama dua atau tiga minggu, sebagai salah satu mata kuliah wajib atau pilihan dari Perguruan Tinggi masing-masing. Dari profil wisatawan yang banyak berkunjung ke Lebakmuncang adalah Generasi Millennial (Generasi Z), 
dimana sebagian guru dan dosen mereka pun adalah Millennial juga (Generasi Y). Jadi dapat dikatakan bahwa target pasar utama dari Desa Lebakmuncang adalah generasi muda (Generasi Millennial).

Generasi Y, Z, dan Alfa, atau biasa kita sebut Millenial. Generasi Y lahir antara 1980 hingga 1995, sedangkan Generasi Z lahir antara 1995 hingga 2010, dan Generasi Alfa lahir pada 2010 dan sesudahnya [8]. Gen Y paham internet dan menggunakan e-mail, ponsel, dan pesan teks untuk berkomunikasi. Lebih dari 90\% dari kelompok berusia 18-29 tahun aktif dalam dunia online dan media sosial seperti Blog, YouTube, MySpace, Facebook, dan Twitter. Jejaring sosial yang dimiliki Millennial adalah ciri khas utama utama untuk generasi ini [9]. Media sosial juga menjadi sumber informasi yang penting bagi Millennial dalam mengambil berbagai keputusan, termasuk pengambilan keputusan pembelian atau konsumsi barang atau jasa.

Sebagai industri yang padat-informasi [10], penting bagi pengelola kegiatan pariwisata untuk memahami adanya perubahan dalam teknologi yang digunakan dan perilaku konsumen yang berdampak pada distribusi dan aksesibilitas informasi terkait perjalanan wisata [11]. Internet menyediakan jumlah informasi yang hampir tak terbatas dengan pengeluaran yang relatif minim [12]. Berdasarkan hasil wawancara dan diskusi kami dengan Ketua Pokja dan masyarakat, Desa Wisata Lebakmuncang ini cukup banyak didatangi oleh wisatawan. Dalam sebulan saja, jumlah rombongan yang datang berkunjung bisa mencapai tiga atau empat rombongan, atau bahkan lebih. Tamu atau wisatawan yang berkunjung pun sangat beragam. Mereka menyatakan bahwa banyak wisatawan tertarik untuk datang ke Desa Wisata Lebakmuncang karena melihat informasi yan disampaikan di media sosial (Website, Facebook, dan Youtube).

Tim UI menilai, informasi yang ditampilkan di media sosial Desa Wisata Lebakmuncang cukup lengkap dan menarik. Hal ini memudahkan masyarakat dan calon wisatawan yang berminat untuk berkunjung ke saana untuk mencari dan mendapatkan informasi dengan upaya dan pengeluaran minim tentang Desa Wisata Lebakmuncang. Kang Asep dan Kepala Dusun Lebakmuncang, yaitu Bapak Iri Suhaeri menjadi contact person yang dicantumkan di website Desa Wisata Lebakmuncang (https://desawisatalebakmuncang.wordpress.com/) atau laman facebook Desa Wisata Lebakmuncang (https://www.facebook.com/desawisata.lebakmuncang) Kang Asep dan Bapak Iri inilah yang menjadi pusat informasi tentang wisata di Lebakmuncang. Mereka berdua lah yang kemudian berkomunikasi dengan wisatawan yang berminat untuk berkunjung dan memberikan penjelasan kepada mereka tentang paket dan produk wisata di Lebakmuncang.

Teknologi internet memungkinkan penggunaan media sosial dalam perencanaan travelling wisatawan, Dari berbagai bentuk media sosial, yang biasa disebut juga sebagai Consumer-Generated Content, Website, Blog, Facebook, Twitter, Instagram, Youtube, Tinder, dan lain-lain. Wisatawan mendapatkan informasi baik dari pengelola tempat wisata, maupun informasi yang diunggah oleh wisatawan lain yang pernah berkunjung ke tempat wisata tersebut. Biasanya para wisatawan yang pernah berkunjung akan menyampaikan pengalaman pribadinya dalam berkunjung ke tempat wisata, komentar, pendapat, dan penilaian mereka lewat berbagai media sosial [13]. Bahkan, konten perjalanan yang diunggah oleh wisatawan yang pernah berkunjung ke tempat wisata dianggap lebih kredibel dan dapat dipercaya daripada ulasan dari para profesional atau informasi pemasar [14].

Pariwisata juga merupakan salah satu sektor dari jasa yang ciri atributnya atau pengalaman penggunaannya tidak dapat dievaluasi atau dideteksi, sebelum merasakan atau merasakan pengalaman berwisata [15]. Informasi tentang tempat atau atraksi wisata yang ditampilkan di media sosial sangat membantu wisatawan untuk mendapatkan gambaran dari tempat atau atraksi wisata yang akan dituju. Situs web dirancang untuk mencerminkan atribut-atribut yang ditawarkan di tujuan/tempat wisata, sehingga mempengaruhi citra yang dirasakan dari tujuan/tempat wisata, dan menciptakan pengalaman virtual bagi konsumen [15]. Intensi dan kegiatan berwisata dapat dipengaruhi oleh tampilan tentang aktivitas yang terkait dengan jalan-jalan, budaya, dan peninggalan budaya Chow dan Murphy [16], yang ditampilkan di situs web tempat wisata yang mencerminkan atribut-atribut dan aktivitas-aktivitas tersebut [17].

Video yang ditampilkan di Channel Youtube Desa Wisata Lebakmuncang menampilkan atraksi yang dirasakan para wisatawan yang berkunjung ke Lebakmuncang [18]. Channel Youtube ini dibuat dan dikelola oleh Pokja Desa Wisata Lebakmuncang. Pokja biasanya membuat video dengan menggunakan Smartphone dan mengunggahnya ke Channel Youtube. Selain video yang diunggah di Channel Youtube Desa Wisata Lebakmuncang, ada beberapa video tentang 
Lebakmuncang yang diunggah oleh wisatawan yang pernah berkunjung dan berwisata ke Lebakmuncang.

Pengalaman berwisata di Lebakmuncang yang ditampilkan di Channel Youtube dijadikan referensi dan informasi tentang bagaimana gambaran aktivitas yang dapat dilakukan oleh para calon wisatawan yang berminat dan berniat untuk datang ke Lebakmuncang. Namun calon wisatawan dan masyarakat pada umumnya cenderung lebih percaya dengan unggahan dari orang biasa yang menjadi wisatawan, dibandingkan dengan unggahan yang dilakukan oleh Pokja. Sehingga Pokja dapat menghimbau wisatawan yang pernah berkunjung untuk mengunggah video menarik tentang wisata Lebakmuncang di Youtube, disertai dengan hastag, yang memudahkan orang untuk menemukan di bagian pencarian Youtube. Karena target utama dari Desa Wisata Lebakmuncang adalah para millennial, yang paling senang melihat Youtube sebagai referensi terkait perencanaan wisata, maka penggunaan Youtube adalah media promosi yang strategis untuk menyasar para Milennial ini.

Dari hasil kunjungan ke Desa Wisata Lebakmuncang, para Pengurus dan Anggota Kompepar dapat melakukan benchmarking dari strategi promosi yang dilakukan oleh Desa Wisata Lebakmuncang. Strategi promosi lewat media sosial terutama lewat Youtube yang dilakukan oleh Desa Wisata Lebakmuncang terbukti dapat meningkatkan jumlah kunjungan wisatawan ke Lebakmuncang. Strategi promosi ini sepertinya patut dicoba juga oleh daerah wisata lain, termasuk daerah wisata yang dikelola oleh Kompepar Cianjur.

\section{KESIMPULAN}

Adapun kesimpulan dari analisis tersebut di atas adalah :

1. Desa Wisata Lebakmuncang merupaka salah satu tempat wisata yang menerapkan konsep Pariwisata berbasis Komunitas (Community-based Tourism).

2. Target utama dari Desa Wisata Lebakmuncang adalah Millenial (Generasi Y dan Z).

3. Media promosi Media Sosial (terutama Youtube) sangat efektif untuk menarik wisatawan untuk dating berkunjung ke Desa Wisata Lebakmuncang, terutama Generasi Milennial

4. Strategi promosi lewat media sosial di Desa Wisata Lebakmuncang dapat dijadikan benchmark oleh Kompepar Cianjur dalam mengelola daerah wisatanya masing-masing.

\section{SARAN}

Setelah kami melakukan kegiatan kunjungan dan melakukan analisis terhadap strategi promosi Desa Wisata Lebakmuncang lewat media sosial, maka Tim UI memberikan saran kepada Pokja Desa Wisata Lebakmuncang agar lebih meningkatkan kualitas tampilan dari media sosial yang dikelola oleh Pokja, Hal ini dilakukan agar informasi yang disampaikan kepada masyarakat lebih detail, lengkap, dan menarik tentang aktivitas wisata yang dapat dilakukan di Lebakmuncang.

Untuk media Youtube, akan lebih baik kalau video yang diunggah oleh Pokja adalah video dengan teknik pengambilan gambar yang lebih baik, sehingga menggambarkan suasana dan aktivitas wisata Lebakmuncang yang lebih menarik lagi. Selain itu juga Pokja dapat menghimbau kepada wisatawan yang oernah berkunjung untuk mengunggah video tentang Lebakmuncang, supaya lebih memviralkan lagi wisata di Lebakmuncang.

Kompepar Cianjur dapat mencontoh strategi promosi lewat media sosial yang dilakukan oleh Desa Wisata Lebakmuncang. Harapannya, dengan mengadopsi promosi lewat media sosial, terutama Youtube, maka kunjungan wisata ke daerah wisata yang dikelola oleh Kompepar Cianjur dapat meningkat, seperti yang terjadi di Desa Wisata Lebakmuncang.

Sedangkan saran untuk kegiatan penelitian dan pengabdian masyarakat selanjutnya adalah dapat menggali bagaimana persepsi dari wisatawan tentang pengalaman berwisata mereka di Desa Wisata Lebakmuncang, juga apakah mereka puas atau tidak dengan layanan wisata yang diberikan.

\section{UCAPAN TERIMA KASIH}

Tim UI mengucapkan terima kasih kepada Kemenristek Dikti yang telah memberikan pendanaan Hibah Penelitian Terapan Unggulan Perguruan Tinggi (PTUPT) tahun 2018. Selain itu kami juga mengucapkan terima kasih kepada para asisten yang membantu pelaksanaan rangkaian 
kegiatan yang terkait dengan penelitian dan pengabdian masyarakat yang kami lakukan, yaitu kepada Israul, Anggada, Denura, Ayu, Indri, dan Sayef.

\section{DAFTAR PUSTAKA}

[1] Mtapuri, O., \& Giampiccoli, A. 2018, Tourism, Community-based Tourism and Ecotourism: a Definitional Problematic, South African Geographical Journal, Ed. 1, Hal 14.

[2] Blackstock, K. J. C., 2005, A Critical Look at Community-based tourism, No. 40, Vol 1, hal 39-49.

[3] Dodds, R., Ali, A., \& Galaski, K., 2018, Mobilizing Knowledge: Determining Key Elements for Success and Pitfalls in Developing Community-based Tourism, Current Issues in Tourism, No. 21, Vol 13, hal 1547-1568.

[4] Zapata, M. J., Hall, C. M., Lindo, P., \& Vanderschaeghe, M., 2011, Can Community-based Tourism Contribute to Development and Poverty Alleviation? Lessons from Nicaragua. Current Issues in Tourism, No. 14, Vol 8, hal 725-749.

[5] Sutedjo, A., Prasetyo, K., \& Sudaryono, L., 2018, Condition of Karangkepatihan Village Community Balong District Ponorogo Regency in Supporting Development of Communitybased Tourism, No. 953, Vol 1, hal 12175.

[6] Kurniasih, Dyah, M. N., Syafitri, A. S., \& Fajri, N. W., 2018, Tourism Village Model based on Local Indigenous: Case Study of Nongkosawit Tourism Village, Gunungpati, Semarang. Paper presented at the , 31 doi:http://remote-lib.ui.ac.id:2090/10.1051/e3sconf/20183109011 Retrieved from https://remote-lib.ui.ac.id:2155/docview/2038389945? accountid=17242

[7] https://desawisatalebakmuncang.wordpress.com/ diakses tanggal 4 maret 2019.

[8] Bencsik, A., Horváth-Csikós, G., \& Juhász, T., 2016, Y and Z Generations at Workplaces. Journal of Competitiveness, Vol 8, No. 3.

[9] Williams, K. C., Page, R. A., Petrosky, A. R., \& Hernandez, E. H., 2010, Multi-generational Marketing: Descriptions, Characteristics, Lifestyles, and Attitudes. The Journal of Applied Business and Economics, Vol 11, No. 2, hal 21.

[10] Nezakati, H., Amidi, A., Jusoh, Y. Y., Moghadas, S., Aziz, Y. A., \& Sohrabinezhadtalemi, R., 2015, Review of Social Media Potential on Knowledge Sharing and Collaboration in Tourism Industry. Procedia - Social and Behavioral Sciences, Vol 172, hal 120-125.

[11] Fesenmaier, D. R., Wo“ber, K., \& Werthner, H., 2006, Introduction: Recommendation Systems in Tourism. In D. R. Fesenmaier, K. Wo"ber, \& H. Werthner (Eds.), Destination Recommendation Systems: Behavioral Foundations and Applications. Wallingford, UK: CABI.

[12] [12] KIM, Dae-Young; Lehti, Xinran Y.; Morrison, Alastair M., 2007, Gender Differences in Online Travel Information Search: Implications for Marketing Communications on the Internet. Tourism Management, Vol 28, No. 2, hal 423-433.

[13] [13] Friedman, T. L., 2006, The world is Flat, New York: Farrar, Straus and Giroux.

[14] [14] Amaro, S., Duarte, P., \& Henriques, C., 2016, Travelers' Use of Social Media: A Clustering Approach, Annals of Tourism Research, Vol 59, hal 1-15.

[15] [15] Lovelock, C., \& Patterson, P., 2015, Services Marketing. Pearson Australia.

[16] Sparks, B.A., Browning, V., 2011. The impact of online reviews on hotel booking intentions and perception of trust. Tourism Manage. 32, 1310-1323.

[17] Chow, I., Murphy, P., 2011, Predicting Intended and Actual Travel Behaviours: an Examination of Chinese Outbound Tourists to Australia. J. Travel Tourism Mark. Vol 28, hal 318-330.

[18] https://www.youtube.com/channel/UCB8Wgf5WbNe3GBcGLcXz Pg diakses pada tanggal 4 April 2019. 